\title{
ENHANCING LEARNERS' GRAMMAR KNOWLEDGE OF TENSES AND VOICE THROUGH “TENSE AND VOICE STRUCTURED WHEEL"
}

\author{
NAZIFULLAH NIJAT ${ }^{1,2}$, ABDUL QUDOS KARIMI ${ }^{1,2}$, WALI KHAN MONIB ${ }^{1,3}$, \\ MOHD HIZWAN BIN MOHD HISHAM ${ }^{1}, \&$ NOR FARAHWAHIDA BINTI ABDUL RAHMAN ${ }^{1}$
}

1, School of Education, Faculty of Social Sciences and Humanities, Universiti Teknologi Malaysia, UTM Johor Baharu, Malaysia 2, Department of English, Faculty of Education, Paktiak University, Paktika, Afghanistan

3, Department of English, Faculty of Languages and Literature, Sheikh Zayed University, Khost, Afghanistan

\begin{abstract}
The purpose of the current study is to develop learners' grammar knowledge of the tenses and voice aspects in writing and speaking. The identified problem is that learners fail to produce or use grammatically appropriate form of language in EFL classrooms especially in tenses and voice. Hence, the research reports whether the proposed product "Tenses and Voice Structured Wheel" has the potential to overcome the stated problem. Thirty-seven upper primary 6students were chosen to participate in one-week intervention program. Pre-experimental research design was employed where both pre- test and post- test were administered to collect the data. The collected data was analyzed through paired samples t-test. The result reveals that there is a statistically significant difference between the scores of pre-test and post-test where, the post -test scores $(M=66.13, S D=3.3)$ are 19.44 points higher than the pre-test scores $(M=46.7027, S D=6.64)$. This indicates that students have shown significant improvement in acquiring the knowledge of tenses and voice.

KEYWORDS: Grammar, Tenses, Voice, Tenses and Voice Structured Wheel \& EFL classroom
\end{abstract}

Received: Jun 09, 2020; Accepted: Jun 29, 2020; Published: Sep 21, 2020; Paper Id.: IJMPERDJUN20201370

\section{INTRODUCTION}

As education, economy, and society are globalizing rapidly, living in the twenty-first century requires students to acquire the skills of communication and technology (Wang, 2010). For the purpose of acquiring communication skills, it is compulsory to learn the English language which has become a significant lingua franca and medium of communication around the world. Consequently, learning English language has become significant in the education system of every nation in this so-called global village.

Generally, English language is taught as a second or foreign language at school level in many countries. Nevertheless, students' performance and level of competency to speak or write using the target language is still questionable, hence leading to frustration among the students and parents. Among the main reasons that lead to the failure in acquiring English language are less explicit grammar instruction and the use of traditional teaching methods like the grammar translation method (Richards, 2006). Hence, mixed methods of teaching should be employed together with the use of authentic materials in order to increase students' linguistic and communicative competency. Effective acquisition of second or foreign language is also dependent on teaching that focuses on all main and subskills of a language. Review on the history of language instruction shows that among other skills, grammar plays a central and vital role in learning a language.

According to Wang (2010), the teaching and learning of a language should focus on the aspect of grammar 
as it not only improves students' writing but also helps them to achieve better understanding in reading and listening comprehension. However, the idea of how to teach grammar is debatable. The study further states on the importance of grammar and concludes that it is grammar that enables humans to talk about a language. In all languages including English, grammar names different types of words and word groups to make a complete sentence. The knowledge of grammar allows learners to construct sentences, form a speech, and produce complete sentences with accurate grammar and semantic. Furthermore, Mart (2013) suggests the inclusion of grammar instruction in a foreign language learning program as it helps learners to understand how language functions and discover the nature of language. Without grammar, language acquisition will be confusing and students will not be able to use the language correctly. Richards and Renandya (2002) have identified two important reasons for teaching grammar, namely comprehensibility and acceptability. Comprehensibility is knowing how to build, and use certain structures, hence making it possible to successfully communicate common types of meaning. Without these structures, it is difficult to make comprehensible sentences, So teachers must attempt to identify these structures and teach them well to the students. Meanwhile, in the context of acceptability, serious deviance from the norms of the native-speakers can hinder integration and excite prejudice. For instance, a person who speaks 'badly' may not be taken seriously or may be considered uneducated. Students may, therefore, want or need a higher level of grammatical correctness than is required for mere comprehensibility.

The discussion above hence lays the foundation for second or foreign language learning where both teachers and learners nd teachers should be aware of its importance and allocate enough time to acquire it. Generally, tenses and passive voice are considered important in grammar, yet they are difficult to be taught. According to Hinkel (2002), teaching passive voice (its functions, usage, and meanings) is labeled as the thorniest problem for teachers in teaching second or foreign language grammar. Similarly, speakers of first language (L1) face much difficulties in constructing passive voice. Most EFL/ESL learners study the derivation structures of passive voice at the intermediate and higher proficiency levels and master them through different exercises. However, when speaking or writing in a second or foreign language (L2), the majority of learners, including those at the advanced level, fail to form accurate construction of passives and use it in appropriate contexts (Hinkel, 2002). Furthermore, the mastery of correct tense usages which hinders learners' acquisition of a foreign language is another problem faced by EFL/ESL learners. Rahman and Ali (2015) suggest that learners' failure in acquiring English tenses is due to "little effort is rendered to the factors that facilitate or hinder the acquisition systems of tense and aspect, therefore, a lot of English as a Foreign Language (EFL) learners fail to master tense and aspect even though they spend substantial amount of time in order to master them". They further state that the most observed difficulties faced by EFL/ESL learners in English tenses are (1) Verb Form, where learners fail to use the verbs properly while expressing the time of an event; and (2) Mother Tongue interference (influence), where learners attempt to apply the rules of their mother tongue on the target language which leads them to produce meaningless sentences.

Elmadwi (2015) reports that among the factors that affect learners' proficiency in second or foreign language grammar include text types, school and social environments, students' intelligence, learning motivation, teaching methods, learning strategies, as well as systematic errors. Among the examples of systematic errors are the interference from the mother tongue, over-generalization, ignorance of rule restriction, and incomplete application of rules and false hypothesized concept.

\subsection{Problem Background}

English is taught as a foreign language at primary and high schools across Afghanistan. By completing high schools, students 
are expected to master and become fluent speakers of English language. This will allow students to access information written in English that are relevant to their studies. Students can only produce and understand correct language by acquiring the essential knowledge of grammar. The Afghan government's policy is to strengthen English language acquisition of the students and prepare them to meet the needs of the $21^{\text {st }}$ century. Nevertheless, the government is struggling to design a standard curriculum in producing proficient speakers of the target language. For this reason, the curriculum is changed several times in order to achieve the stated aims.

Based on past teaching experiences, we encountered that students mainly have problems in mastering tenses and voice. They make mistakes in the proper usage of verb forms and choice of verb tenses as they attempt to express the time of an event in the target language. For instance, they say "it is raining for three days." while the correct form is "it has been raining for three days." Another common error in the usage of tenses that students face whilst communicating with other people is using incorrect tense form in complex sentences. For example, students say, "I will call you when the class will be ready."; however, the correct form is "I will call you when the class is ready." EFL learners' native language (L1) influence can be claimed to be one of the reasons behind their failure to acquire tenses of the target language (TL). Thus, interference of L1 and the lack of knowledge of TL grammar cause students to feel demotivated to speak and write in English language.

In case of passive voice, the semantic class of the passive voice is considered to have a distinctive syntactic and morphological awareness in many languages (Nabeel, 2017) where different languages have different rules of grammar to apply passivation. Since tenses in Pashto and English language are different, the pattern varies as well. As a result, students face significant difficulties to learn passive voice with specific struggle on the aspect of subject-verb agreement, missing verb "to be", as well as incorrect usage of participles and prepositions that related with main verb before the by phrase. For instance, students tend to be confused by the preposition of "with" and "in" where they were unable to change some sentences from active to passive voice during in-class activities as shown in Table 1:

Table 1: Sample of Students' Errors in Voice

\begin{tabular}{|c|l|l|l|}
\hline No. & Given Sentence (Active) & \multicolumn{1}{|c|}{ Students Utterances (Passive) } & \multicolumn{1}{|c|}{ Correct Forms (Passive) } \\
\hline 1. & $\begin{array}{l}\text { Your performance pleased } \\
\text { me. }\end{array}$ & I was pleased by your performance. & $\begin{array}{l}\text { I was pleased with your } \\
\text { performance. }\end{array}$ \\
\hline 2. & This can contains oil. & Oil is contained by this can. & Oil is contained in this Can. \\
\hline 3. & Smoke filled the room. & The room was filled by smoke. & The room was filled with smoke. \\
\hline 4. & People grow rice in India. & $\begin{array}{l}\text { Rice is grown by people in India. (correct but } \\
\text { poor) }\end{array}$ & Rice is grown in India. (better) \\
\hline
\end{tabular}

According to Ryan (2010), there are six problems that students often face in writing which include lack of vocabulary, grammar, and sentence mastery. Hence, teachers should employ appropriate teaching and learning activities in accordance with students' needs as well as the aims of the course (Mestari \& Malabar, 2016).

\subsection{Theoretical Background}

The proposed product is based on Krashen's (1982) theory of second language acquisition known as the Monitor Model theory (Input Hypothesis) and Johnson \& Johnson's (1994) Cooperative Learning theory. According to Liu (2015), Input Hypothesis suggests that language is acquired by receiving "comprehensible input" that is slightly above learners' current level of competence $(i+1)$ where " $i$ " represents learners' current knowledge of second language and “+ 1 ” represents structures that are slightly beyond their current level of competence. Krashen (1985) believes that comprehensible input (i+1) can lead to acquisition where unknown structures are acquired with the help of contextual information. The hypothesis has two 
convictions: first, speech would emerge, rather than being taught, as a result of acquisition through comprehensible input with competence successfully built; second, grammar is automatically acquired if comprehensible input is received and there is enough of it. Students are provided with flash cards with scrambled words written on the back and the organized forms of the same words written on the front side. TVSW-based activities can be practiced individually, in pairs, as well as in groups. For instance, teacher can assign students in pairs and invite them to the front of the class. One of the students shall turn the Wheel and as it stops on a structure indicated with the arrow, the other student will take one flash card related to the structure from the envelope. The student will then read the words on the back of the flash card as an input, arrange the words, and write them on the board, hence producing a grammatically correct sentence as an output.

Cooperation exists when individuals work together in a group in order to promote their individual learning outcomes as well as the learning outcomes of their peers (Johnson \& Johnson, 1989). According to the Cooperative Learning theory, cooperation is most effective when students perceive that they share similar goals, and when the individual members' goals are positively dependent on the actions of the group. The five basic elements of the Cooperative Learning theory proposed by Johnson and Johnson (1994) are individual accountability, positive interdependence, face to face promotive interaction, group processing, and interpersonal and small group skills. As mentioned earlier, the activities can be done in pairs as well as in groups which will provide opportunities for students to have face to face interactions with each other. In addition, students will be consistent in practicing their work in class as well as at home, thus demonstrating their individual accountability. It will also improve other significant skills such as asking questions, sharing their ideas regarding the provided structures, and being respectful to one another.

\subsection{Need Analysis}

Need can be described as the space between the current and expected conditions. A questionnaire was administered to Nine EFL teachers whose teaching experiences range from 1 to 15 years. Findings from the questionnaire show that the common problems faced by EFL students include inconsistent usage of verb forms, switching between present and past tense, incorrect usage of subject-verb agreement in terms of passive voice, using incorrect past participle of irregular verbs, and ignoring verb "to be" in passive structures. The result of the questionnaire is shown in Figure 1.

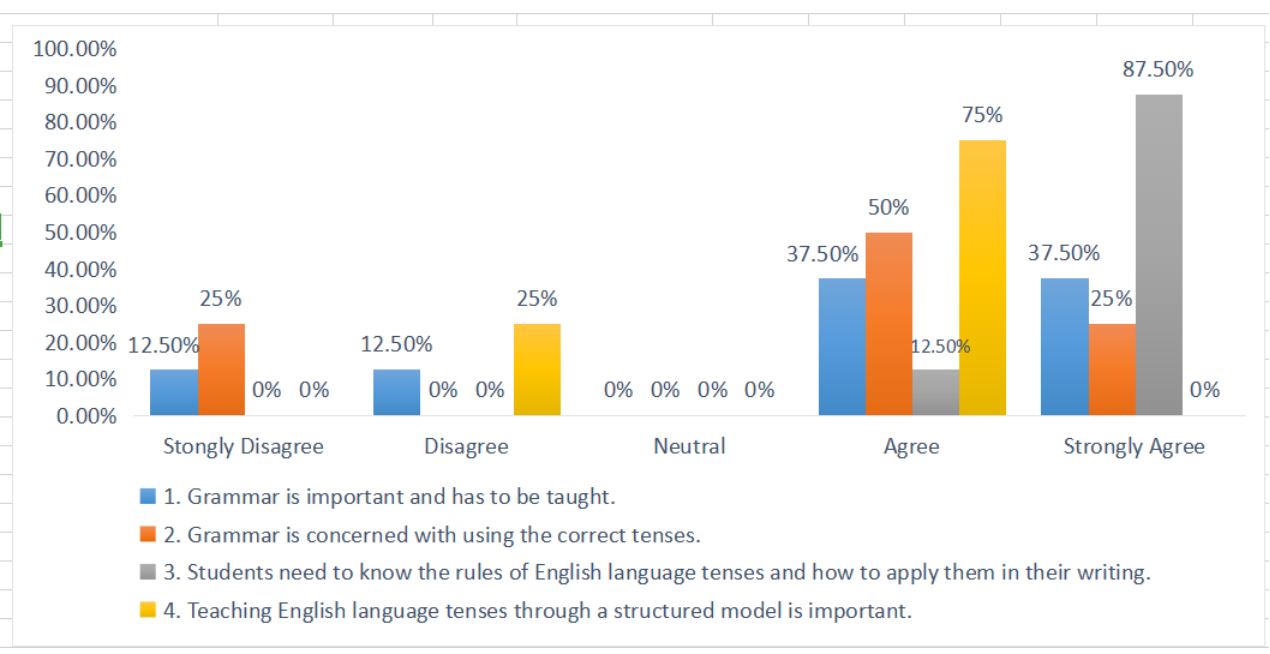

Figure 1: EFL Teachers' Attitude Towards Grammar. 
Figure 1displays the first four items of the questionnaire in relation to the EFL teachers' attitude towards grammar. 87.5\% of the respondents strongly agree that students need to know the rules of English tenses and how to apply them in their writing. Subsequently, 75\% respondents agree that teaching English tenses through a structured model is important while only two respondents disagree with this idea. Meanwhile, 25\% respondents strongly agree that grammar is concerned with using correct tenses followed by 50\% who agree with the statement respectively. Finally, $37.5 \%$ respondents strongly agree and $37.5 \%$ respondents agree that grammar is important and has to be taught while only $12.5 \%$ respondents disagree and $12.5 \%$ respondents strongly disagree with the statement.

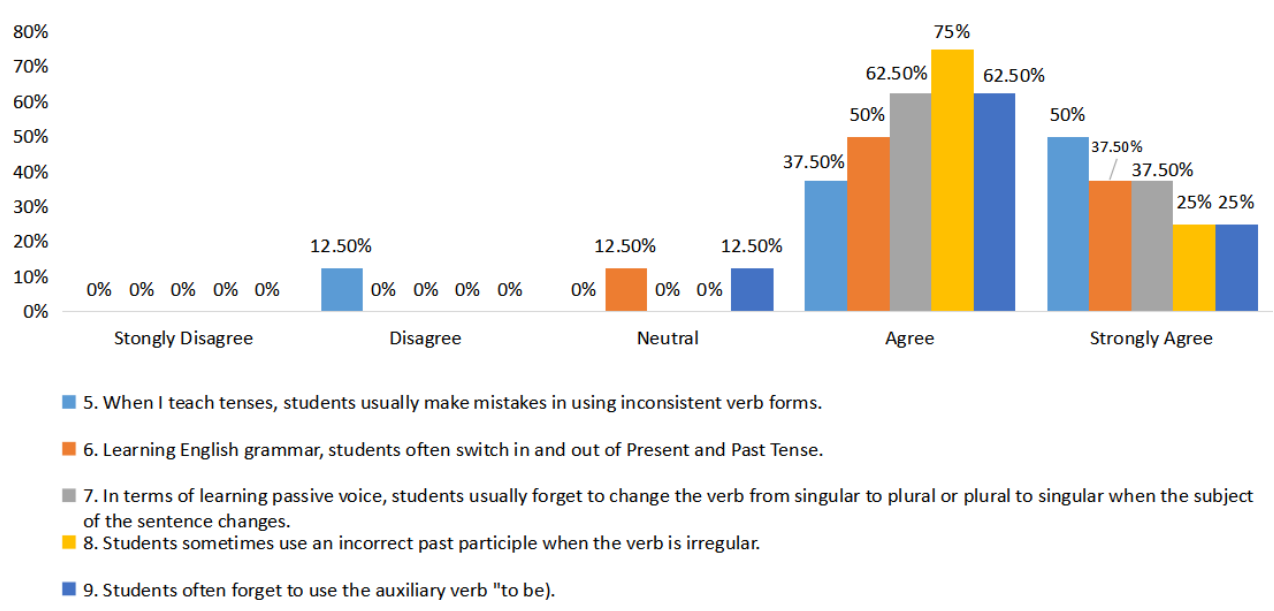

Figure 2: EFL Teachers' Attitude towards Students' Errors in Tenses and Voice.

Figure 2 indicates that $75 \%$ respondents agree and $25 \%$ respondents strongly agree that the most common error produced by students is incorrect formation of past participle when the verb is irregular. Meanwhile, $62.5 \%$ respondents agree and $37.5 \%$ respondents strongly agree with item 7 regarding learning passive voice where students tend to forget to change the verb from singular to plural or vice versa when the subject of the sentence changes. Subsequently, $62.5 \%$ of the respondents agree and $25 \%$ of them were strongly agree with item 9 where students often forget to use the auxiliary verb "to be". Meanwhile, $50 \%$ of respondents agree, $37.5 \%$ strongly agree, while only $12.5 \%$ respondents are neutral to the statement where students often switch between the present and past tense as they learn the English grammar. Finally, 50\% of the respondents strongly agree, $37.5 \%$ agree, and only $12.5 \%$ respondents disagree with item 5 of "when I teach tenses, students usually make mistakes in using inconsistent verb forms."

\section{LITERATURE REVIEW}

\subsection{Tenses in English Language}

Tense denotes the time when an action happens or takes place during the past, present, and future (Cowan, 2008; Salaberry \& Shirai, 2002). However, there are numerous traditional English verb tenses definitions that are often unsatisfactory, complicated, and confusing (Capua, 2017). Some linguists believe that tense only comprise the present and past where future is considered part of the present (Çakır, 2011) while other linguists denote that tenses comprise three dimensions of present, past, and future (Cowan, 2008). In this regard, present tense describes an action or event which occurs at the moment. It also explains things in general, describes regular or habitual actions, and represents facts, routines, daily activities, and instructions. On the other hand, past tense refers to activities, actions, and events that occurred in the past, and it is usually used for storytelling, narrative, and recount texts. Meanwhile, future tense indicates actions that are yet to happen.

Knowing language aspects including tenses is believed to be crucial to promote proper language usage among 
learners. Similarly, learning how to use the tenses help us to make clear and effective use of the language though it is the challenging part to learn for EFL and ESL students in English grammar (Napratilora \& Siagian, 2019) being failed to develop on the stressed point efficiently (Çakır, 2011). Wahyuningtyas and Bram (2018) conducted a study on the comprehension of basic English tenses among first semester English language students at the Sanata Dharma University, Yogyakarta. The result indicates that students have problems to understand the basic tenses especially in remembering the formula. Another study conducted by Amadi (2018) involving students who enroll into the English and Communication Art program at the Agnatius Ajuru Uiversity of Education, Nigeria found that the most difficult aspects for students are tenses and changes of the verb phrases. Similarly, Rahman and Ali (2015) reveal that the knowledge on tenses and aspect is significant for language users to express themselves. They also argue that students tend to make tenses-related mistakes even in the advanced level.

\subsection{Aspects of Tenses}

Aspect concerns on different perspectives that a speaker can take and express with regards to the temporal course of an event, action, or process (Klein, 2013). In other words, aspect refers to how speakers see an event. According to Cowan (2008), aspect expresses how speakers view the action of the verb. For example, an action that is seen as bounded and completed is perfect in aspect. In this regard, if the action is seen as incomplete, it is imperfect in aspect; if seen as repeated, it is iterative; and if seen as occurring regularly, it is habitual. Furthermore, passive voice has been discussed extensively apart from the aspects of tenses (Caponigro \& Schütze, 2003; Embick, 2004; Kallulli, 2007; Castillo, 2009; Kiparsky, 2013; Breul, 2004; Breul, 2014).

The following examples distinguish between tenses and aspects:

- She is reading now. Present Progressive

- She has eaten the mango. Present Perfect

We know the difference between example one and two through the aspect since both are in the present tense. In order to know, not only the form but also the functions, it is must to figure out tense along with its aspects. As Flora and Hasan (2012) assert that tenses cannot transfer the different meanings between two sentences while being in the same tense, it justifies the need to understand aspect as well.

\subsection{Concept of Passive Voice and Its Usage in English Language}

The voice of a sentence refers to the relationship between a subject and a verb. Passive voice is a grammatical structure where the object of a verb takes the place of the subject. The noun functioning as the grammatical subject is typically the recipient of the action denoted by the verb rather than the agent and may be used to avoid assigning responsibility to the doer (Choomthong, 2011; Crystal, 2008). In an English passive sentence, "the logical subject-the agent-moves out of the position of grammatical subject and is relegated to a by-phrase" (Brinton \& Brinton 2010; Lubis, et al., 2019). Therefore, constructing passive voice involves the inversion of the noun phrase (NP) subject and NP object position.

The inversion of the NP-subject and NP-object position affects the verb structure of an active sentence. The English language constructs its verbs in the passive voice through the use of the verb "to be" and the verb "to get". The former method, also known as the "be-passive", is the most common where it is often used with the past participle of a lexical verb such as "He was flogged by the teacher". This method of passivizing the verb appears in all levels of English, however its 
only restriction is that the verb must be transitive. Meanwhile, the latter, known as the "get-passive", is used in less formal situations and it is restricted to a small number of verbs such as get burned, get hurt, get stuck, get shot, get paid, and get arrested. This paper focuses on the "be-passive" method in which the doer of the action is optional, unimportant and may be omitted (Wilson \&Wauson, 2010; Coffn, Hewings \& O’Halloran, 2004).

Extensive discussions have been conducted to decide whether to use active or passive voice (Armstrong \& Dienes, 2014; Altstiel \& Grow, 2015; Thompson \& Scheepers, 2013; Freeman, 2009; Berry, 2012). Several studies have investigated to determine where and when a specific voice is preferred to the other (Thompson, Ferreira \& Scheepers, 2018). For example, many academic writers use passive voice as a way of communication (Biber, Johansson, Leech, Conrad \& Finegan, 2000) and around one third of the scientific works are written in passive voice verbs (Master, 2004). This contributes variety to the writing, soften orders, protect feeling (Booher, 2001) and avoids writers from subjectivity. On the other hand, passive voice is considered inappropriate in technical writing as it obscures the idea. This is supported by Jain (2013) who states that passive voice is a wrong choice in technical writing. Also, the American Psychological Association (APA, 2009) suggests on the use of active voice as opposed to passive voice in writing.

However, both active and passive voice are the complementary and interrelated forms of sentence in terms of meaning (Thompson, Ferreira \& Scheepers, 2018; Altenberg \&Vago, 2010). This posits that the two variants of voice are grammatically correct, and it is only a matter of importance to either the doer or the receiver.

\subsection{Factors Affecting the Teaching and Learning of Grammar}

Grammar is often considered as an obstacle in learning any language especially in the non-native context. Both teachers and learners of English as a foreign language struggle to overcome this issue and gain proficiency in the target language. He (2013) believes that the acquisition of English grammar is an indispensable and complex process that needs to be further explored. Lasimatun and Munir (2019) associate English grammar with many red ink and boring rules where grammar classes are often associated with frustration, tiredness, and lack of concentration that gives minimal attention to effects and emotion. Among the factors that hinder the acquisition of grammar include methodology, large class size, multi proficiency levels of students, and time constraints (Nguyen, Warren \& Fehring, 2014).

\subsection{Teaching Methods}

Discussion on the teaching and learning of a language is often associated with the relationship between teaching and learning. Most teachers enter their class with pre-planned activities and strategies that are supported by specific methodology. Hence, teaching is considered as an effort to facilitate learning, guide and encourage learners, and set the conditions for learning (Nguyen, Warren \& Fehring, 2014). Furthermore, having a good understanding on how learners learn will help teachers to determine their philosophy of education as well as their teaching style, approach, methods, and classroom techniques. However, there is a debate over the implementation of teaching methodologies in language classrooms. According to Hashemi and Daneshfar (2018), traditional grammar teaching methods such as grammar translation, direct method, and audio-lingual tend to present and practice specific grammatical points. These approaches are considered as a limited view of grammar teaching where grammar teaching and instruction can occur naturally by exposing learners to certain forms while focusing on the message in the accomplishment of some communicative tasks. Existing empirical evidences report that mere exposure to the target language possesses less potential in promoting the development of grammatical competency. Therefore, it is advisable for language teachers to combine the traditional grammar teaching methodologies 
with new communicative teaching methodologies (Bancolé-Minaflinou, 2018).

\subsection{Large Class Size}

Numerous studies have also reported on the influence of class size towards the efficacy of grammar teaching in language classrooms. In this regard, a language class with a large number of students is often associated with significant drawbacks towards effective grammar teaching as it provides unconducive environment and limited opportunities for teachers to implement quality teaching and learning for the benefit of the learners (Pedder, 2006; Hattie, 2005; Blatchford et al., 2002). According to Bahanshal (2013), teachers find it difficult to manage large classes with students of various proficiency levels. Furthermore, most English teachers favor small classes as it allows the implementation of more in-class activities and subsequently leads towards better learning experience for students as opposed to those in large classes. The study further reports that large English classes do not offer ideal setting for effective teaching and learning such as student-centered teaching and learning to happen. This is supported by Bancolé-Minaflinou (2018) who states that large size class negatively affects the quality of teaching and learning as well as the assessment processes in both in rural or urban setting.

\subsection{The Influences of First Language on the Acquisition of L2 Grammar}

L1 interference is one of the most important and widely studied concepts in the field of language acquisition. Derakhshan and Karimi (2015) believe that first language has an effect on the acquisition of second language where it often interferes with the process of acquiring second language grammar. The role of first language in second language acquisition depends on the similarities and differences between the two languages. Alijani and Berjesteh (2018) state that identifying the proper ways in teaching grammar is one of the most observed difficulties among ELT teachers and first language can play a positive role in language learning especifically in grammar. However, Ahsan, Ghani and Khaliq (2016) believe that first language is a language learning barrier rather than a facilitating tool. According to Sanmuganathan (2014), L1 interference causes structural changes in one or both languages where learners violate the norms of the languages. This leads them to commit various mistakes (morphosyntactic errors) including the placing the elements of sentence in the wrong order and the tendency to overgeneralize grammatical rules such as the use of prepositions.

Hashemi and Daneshfar (2018) suggest that among the main purpose of grammar is to satisfy the need of communication. Hence, teachers are advised to observe several aspects while teaching grammar, such as the provision of instructions that link the grammar forms to its communication context, avoid from separating the grammar forms and the communication context, use a variety of grammar instruction techniques to enforce learning, as well as helping students to apply the acquired rules to express new meanings.

\section{OBJECTIVES}

The objective for this study is:

- To develop a learning tool that enhances learners' grammar knowledge of English tenses and voice.

\section{METHODOLOGY}

\section{Pre-Experimental Design}

A pre-experimental design is a one group pretest and post-test design where experimental manipulation is examined and allows researchers to measure a group on a dependent variable that tests a new method (Cohen, Manion \& Morrison, 2002). It 
follows the basic steps of experimental design without the existence of a control group. This study tests a new product among upper primary $6^{\text {th }}$ students at a private school in Johor, Malaysia through the implementation of a one week intervention. The researchers aim to investigate whether the newly designed product known as the Tenses and Voice Structured Wheel will have an effect on the students' learning. Thirty-seven (37) students were involved in this one-week course of study. After administering the pretest followed by an intervention, the researchers measured the students' learning and proceeded to account for any differences between the pretest and post-test scores.

\section{PROJECT DEVELOPMENT MODEL}

\section{Development Model}

For the purpose of addressing students' weaknesses in learning tenses and voice, the ADDIE Model has been employed to develop a product that meets the students' needs. It is one of the most popular models used as a guide to develop a successful design in the field of instruction. The ADDIE Model provides a basis for systematic and strategic instructional design (Lim, Kim \& Hwang, 2019), designing and developing a special website (Ghani, Malim \& Daud, 2018), constructing training programs (Ma’ruf \& Rochman, 2019), and providing new program (Raoufi, Manoharan \& Haapala, 2019).

ADDIE is an acronym for Analysis, Design, Development, Implementation, and Evaluation (Moradmand, Datta \& Oakley, 2014). This model is a method that aids instructional designers in any subject matter development as well as for teachers to create a well-organized and efficient teaching design by relating the processes of the ADDIE Model to any instructional product (Nada Aldoobie, 2015). The evaluation stage of the ADDIE Model is performed for each phase and for the entire project:

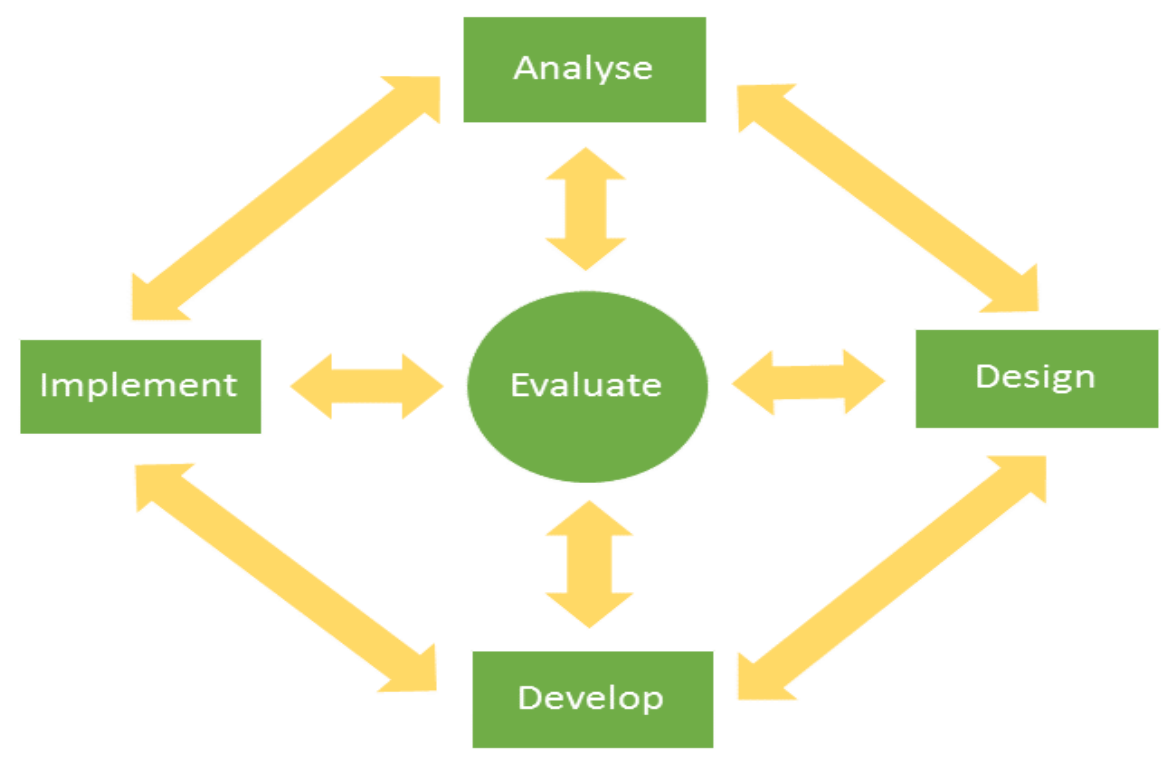

Figure 3: The Iterative Version of the ADDIE Model (Nguyen, 2016).

\section{a) Analysis}

Based on Figure 3, the analysis phase is the first and main stage in this process where needs analysis, target audience analysis, and analysis of topics and tasks are conducted (Moradmand, Datta \& Oakley, 2014; Fao, 2011). In order to conduct the analysis phase, the researchers analyzed the problem, needs, audience, and the task to determine the problem to be 
investigated, which is the students' deficiency in learning tenses and voice. As previously discussed, their lack of tenses and voice knowledge has decreased their motivation to learn as it influences their competency in the four language skills of listening, speaking, reading, and writing. Subsequently, these students struggle in achieving their learning objectives. Hence, it is hoped that the proposed product will help the students to learn and remember the tenses and voice more effectively.

\section{b) Design}

The designing stage comprises processes such as identifying specific objectives, learning activities, educational or pedagogical strategies; designing learning activities; and developing the subject content or materials (Fao, 2011, Moradmand, Datta \& Oakley, 2014). The design instruction can be efficient and helpful that eases the students' learning process through the materials and activities provided. For this to be achieved, the Tenses and Voice Wheel is designed to help students to learn the tenses and voice structures as well as its proper usage in the real context.

\section{c) Development}

Development is the process of realizing the design that encompasses the Analyze and Design phases (Kristanto, Mariono \& Nuryati, 2018; Moradmand, Datta \& Oakley, 2014; Fao, 2011). The aim of this phase is to develop the illustration of the material that transforms the design specifications into a physical product. An important step in this developmental stage is the verification before it is applied to the real content (Kristanto, Mariono \& Nuryati, 2018). The proposed Tenses and Voice Wheel aims to assist students to learn, practice, and apply tenses and voice for both spoken communication and academic writing purposes. Its stress-free nature will also help students to develop social and interpersonal skills and the product may be updated, modified, and improved in terms of its learning content and instructions.

\section{d) Implementation}

The implementation phase refers to the actual delivery of the instruction, learning resources, or a project in a real-world context (Muruganantham, 2015; Nichols Hess \& Greer, 2016; Muruganantham, 2015) such as in the classroom, computerbased, or laboratory-based (Muruganantham, 2015). The aim of this phase is to provide instruction effectively and efficiently. In order to support the students' understanding to the material and aids towards achieving the learning objectives, the number of students involved in the implementation phase is limited to 37 students. This phase will provide structures, patterns, and flash cards for students to enhance and develop their knowledge on tenses and voice in their everyday life.

\section{e) Evaluation}

The evaluation phase ensures that the desired objectives can be achieved by the designed product. This phase determines and evaluates the success and effectiveness of the instruction (Ghani, Malim \& Daud, 2018; Uzunboylu \& Kosucu, 2017). Evaluation will be conducted throughout the implementation phase with the help of the teachers who will administer the evaluation survey among 37 students. It will occur across the entire instructional design process such as within phases, between phases, and after implementation. It is the key to have the necessary information to revise (O'Neill, 2017) and is reflected in order to gain students' opinions about the efficiency of the product. Therefore, the Tenses and Voice Wheel aims to address the students' lack of tenses and voice knowledge and ease their learning. The evaluation of the Wheel is tested via the administration of a pre-test and post-test.

\section{DATA COLLECTION}

The pre-test and post-test method was used to collect the data from the participants in order to determine the outcome of the 
Tenses and Voice Wheel intervention. The participants attempted the pre-test and attended the one-week intervention before they attempted the post-test. Both pre-test and post-test comprise similar set of items on the aspect of tenses and voice. The product was implemented and tested at a private school in Johor, Malaysia and the obtained data were analyzed using paired samples t-test.

\section{DATA ANALYSIS AND RESULT}

Following its meeting of the assumptions, the mean score of the students' pre-test $(\mathrm{M}=46.7027, \mathrm{SD}=6.64)$ is significantly different from the mean score of their post-test $(\mathrm{M}=66.13, \mathrm{SD}=3.3)$ with $t(37)=-18.748, p=.000,95 \% C I(-21.254,-17.34)$. The significant mean difference between the pre-test and the post-test scores is shown in table 2 .

Table 2: Paired Samples t-Test Result of Pre-Test and Post-Test

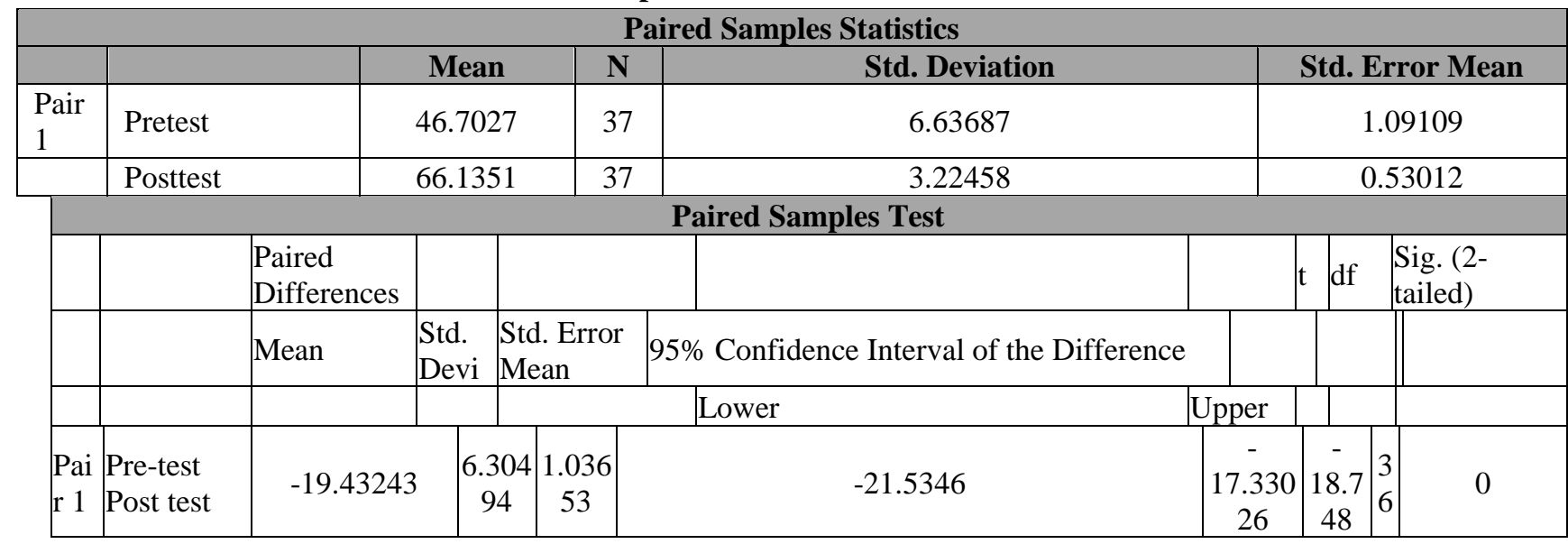

Table 2 shows the paired sample t-test results of the pre-test and post-test for the Tenses and Voice Structured Wheel intervention where a statistically significant difference is recorded. The standard deviation obtained for the intervention indicates more variability and it is widely dispersed among the pre-test scores as compared to the post-test scores. On average, the post-test scores are 19.44 points higher than the pre-test scores. Thus, it is strongly evident that the product has the potential to enhance students' understanding of tenses and voice effectively.

Table 3 shows that sig. level=.038 is less than $\mathrm{P}$ value= $=05$ indicating a significant correlation between the pre-test and post-test. It also denotes a weak positive correlation of $0.5 \leq \mathrm{r}<0.7$ between the pre-test and post-test.

Table 3: Paired t-Test Correlations between Pre-and Post-Test

\begin{tabular}{|l|l|c|c|c|}
\hline \multicolumn{5}{|c|}{ Paired Samples Correlations } \\
\hline & & N & Correlation & Sig. \\
\hline Pair 1 & Pretest \& Posttest & 37 & 0.343 & 0.038 \\
\hline
\end{tabular}

The result in Table 3 indicates that there is a significant weak positive correlation between the mean scores of the pre-and post-test following the one-week Tenses and Voice Structured Wheel intervention. This shows that students who obtain high scores during the pre-test are expected to show excellent performance in the post-test.

\section{DISCUSSIONS}

The purpose of this study is to design a product, namely the Tenses and Voice Structured Wheel, that can enhance the 
learners' grammar knowledge on tenses and voice. The findings reveal that there is a substantial improvement in the performance of students who were intervened using the designed product as evident by the results of the paired sample t-test analysis. Furthermore, the standard deviation dispersion is widely available in the pre-test as compared to the post-test and the mean difference of the post-test is 19.44 points higher than the pre-test. Such result is verified through the alpha value $\alpha=.000$ which is less than the P value $=.05$. In addition, the students' ability to obtain higher scores in the post-test than their initial performance during the pre-test indicates significant improvement in their learning. The findings hence suggest that the implementation of the Tense and Voice Structured Wheel in grammar teaching leads to greater understanding and better performance in tenses and voice among students. However, there are several limitations in this study including time constraint, research design, and research setting.

\section{CONCLUSION AND RECOMMENDATIONS}

This research investigates the effectiveness of the newly designed product Tense and Voice Structured Wheel (TVSW) in enhancing students' grammar knowledge in tenses and voice. The product aims increase the students' understanding on English tenses and voice as well as their social skills which is demonstrated by their cooperation with one another. Such intervention creates a friendly and positive classroom environment where students can exchange knowledge related to the topic. In this regard, attracting students' attention to actively participate in the class as well as creating a friendly and interesting atmosphere is vitally important for learners (Yunus, Salehi \& John, 2013). The pre-test and post-test results show that TVSW has potential benefits in the teaching of grammar among for students. The product may be updated, modified, and improved in terms of the learning content and instructions. In addition, it is also recommended for the TVSW to be digitized as it is simple and can be manually operated.

\section{REFERENCES}

1. Ahsan, M., Ghani, M., \& Khaliq, A. (2016). Teachers' Perceptions toward the Use of Urdu Language in Teaching/Learning English as a Foreign Language. International Journal of Business and Social Science, 7(8).

2. Al-Shatanawi, H. A., Osman, A., \& Ab Halim, M. S. (2014). The Importance of Market Research in Implementing Marketing Programs. International Journal of Academic Research in Economics and Management Sciences, 3(2), 150.

3. Altenberg, E. P., \&Vago, R. M. (2010). English grammar: Understanding the basics. Cambridge University Press.

4. Altstiel, T., \& Grow, J. (2015). Advertising creative: Strategy, copy and design. London, UK: Sage Publications.

5. Amadi, S. C. (2018). Learning the English Passive Voice: Difficulties, learning strategies of Igbo ESL learners and pedagogical implications.

6. American Psychological Association (APA, 2009). Publication manual of the American Psychological Association (6th ed.). Washington, D.C.: APA.

7. Armstrong, A. M., \& Dienes, Z. (2014). Subliminal understanding of active versus passive sentences. Psychology of Consciousness: Theory, Research, and Practice, 1(1), 32.

8. Aws Nabeel, H. (2017). The use of the passive voice in the writing of Arab ESL learners/Aws Nabeel Hameed (Doctoral dissertation, University of Malaya).

9. Azimi, K., Ahmadigo, J., \&Rastegarpour, H. (2015). A survey of the effectiveness of instructional design ADDIE and multimedia on learning key skills of futsal. Journal of Educational and Management Studies, 5(3), 180-186.

10. Bahanshal, D. A. (2013). The Effect of Large Classes on English Teaching and Learning in Saudi Secondary Schools. English 
Language Teaching, 6(11), 49-59.

11. Bandarian, R. (2007). Measuring commercial potential of a new technology at the early stage of development with fuzzy logic. Journal of Technology Management \& Innovation, 2(4), 73-85.

12. Berry, R. (2012). English grammar: A resource book for students. London: Routledge.

13. Biber, D., Johansson, S., Leech, G., Conrad, S., \&Finegan, E. (2000). Longman grammar of spoken and written English. Beijing: Foreign Language Teaching and Research Press.

14. Blatchford, P., Goldstein, H., Martin, C., \& Browne, W. (2002). A study of class size effects in English school reception year classes. British educational research journal, 28(2), 169-185.

15. Booher, D. (2001). E-writing: 21st-century tools for effective communication. New York: NY: Pocket Books.

16. Bram, B. (2014). Language, linguistics and literature: Meaning aspects. In Language and Language Teaching Conference (LLTC) 2014 Proceedings (pp. 289-298).

17. Brinton, L. J., \& Brinton, D. (2010). The linguistic structure of modern English. John Benjamins Publishing.

18. Bueraheng, Nuramal, and Chonlada Laohawiriyanon. "Does learners' degree of exposure to English language influence their collocational knowledge." International journal of english and literature (IJEL) 4.3 (2014): 1-10.

19. Çakır, H. Karataş, S. (2012). Instructional systems development the educational technology theory and application an overview of the process,2(1),19-31.

20. Çakır, I. (2011). Problems in teaching tenses to Turkish learners. Theory and Practice in Language Studies, 1(2), $123-127$.

21. Capua, A. D. (2017). Grammar for Teachers. A Guide to American English for Native and Non-Native Speakers/A. de Capua. New York, Springer.

22. Choomthong D (2011). A case study of learning English passive of Thai EFL learners: difficulties and learning strategies. The Asian conference on language learning official proceedings.74-87.

23. Comrie, B. (1985). Tense (Vol. 17). Cambridge university press.

24. Cowan, R. (2008). The teacher's grammar of English with answers: A course book and reference guide. Cambridge University Press.

25. Crystal, D. (2011). A dictionary of linguistics and phonetics (Vol. 30). John Wiley \& Sons.

26. Derakhshan, A., \& Karimi, E. (2015). The interference of first language and second language acquisition. Theory and Practice in language studies, 5(10), 2112-2117.

27. Elmadwi, H. M. (2015). Problems Encountered by Students at al-Amal Secondary School in Using Passive Voice in Written English. IOSR Journal of Humanities and Social Science, 20(7), 32-38.

28. Fao, E. (2011). learning methodologies a guide for designing and developing e-learning courses. Rome: FAO (Food and Agriculture Organization of the United Nations).

29. Flora, M. A., \& Hasan, S. M. (2012). The semantics of progressive aspect: a thorough study.

30. Freeman, J. (2009, March 22). Active resistance: What we get wrong about the passive voice.

31. Ghani, M. T. A., Malim, T., \&Daud, W. A. A. W. (2018). Adaptation of addie instructional model in developing educational website for language learning. Global Journal Al-Thaqafah, 8(2), 7-16. 
32. Hashemi, A., \&Daneshfar, S. (2018). The impact of different teaching strategies on teaching grammar to college students. Theory and Practice in Language Studies, 8(3), 340-348.

33. Hattie, J. (2005). The paradox of reducing class size and improving learning outcomes. International journal of educational research, 43(6), 387-425.

34. He, H. (2013). On FL learners' individual differences in grammar learning and their grammatical competence training. Theory and Practice in Language Studies, 3(8), 1369.

35. Herrmann, K. J. (2013). The impact of cooperative learning on student engagement: Results from an intervention. Active learning in higher education, 14(3), 175-187.

36. Hinkel, E. (2002). Why English passive is difficult to teach (and learn). New perspectives on grammar teaching in second language classrooms, 233-259.

37. Hinkel, E. (2002). Why English passive is difficult to teach (and learn). New perspectives on grammar teaching in second language classrooms, 233-259.

38. Jain, S. (2013). Technical report writing. New Delhi, India: Centrum.

39. Klein, W. (2013). Time in language. Routledge.

40. Kristanto, A., Mariono, A., \&Nuryati, D. W. (2018, January). Developing Media Module Proposed to Editor in Editorial Division. In Journal of Physics: Conference Series (Vol. 947, No. 1, p. 012054). IOP Publishing

41. Kurniasari, M. D. (2017). Tolerating structural ambiguity in grammar learning. International Journal of Indonesian Education and Teaching (IJIET), 1(1), 85-94.

42. Lasmiatun, I., \& Munir, S. (2019). Potential future of ppp paradigm on efl grammar teaching: An annotated survey. Proceeding Iain Batusangkar, 3(1), 151-158.

43. LAKSHMI, D. VIJAYA, and BHVN LAKSHMI."ENTHRALLING ACTIVITIES OF GRAMMAR. "International Journal of English and Literature (IJEL) 3. 4, Oct 2013, 19-22

44. Lim, D. H., You, J., Kim, J., \& Hwang, J. (2019). Instructional Design for Adult and Continuing Higher Education: Theoretical and Practical Considerations. In Optimizing Instructional Design Methods in Higher Education (pp. 73-100). IGI Global.

45. Liu, D. (2015). A critical review of Krashen's input hypothesis: Three major arguments. Journal of Education and Human Development, 4(4), 139-146.

46. Lubis, B. N. A., Afrilyani, T. P., Girsang, S. W., Sihite, B. M. T., Chandra, S., \&Permadi, A. (2019). An Error Analysis On Changing Active Voice Into Passive Voice At Ninth Grade Of Smp Amir Hamzah Medan. EduTech: JurnalIlmuPendidikandanIlmuSosial, 5(2).

47. Ma'ruf, K. F., \&Rochman, M. M. (2019). Guidelines for developing information security training and awareness programs in government agency: The perspective of addie instructional design models (a case study in indonesian government agency). International Journal of Social Sciences, 5(2).

48. Mart, C. T. (2013). Teaching grammar in context: why and how?. Theory and practice in language studies, $3(1), 124$.

49. Master, P. (2004). English grammar and technical writing. Washington, DC: English Language Programs, Bureau of Educational and Cultural Affairs.

50. Mestari, S. A., \& Malabar, F. (2017). The use of authentic materials in teaching grammar for EFL students (teachers' perspective). LLT Journal: A Journal on Language and Language Teaching, 19(2), 125-131. 
51. Moradmand, N., Datta, A., \& Oakley, G. (2014). The design and implementation of an educational multimedia mathematics software: Using ADDIE to guide Instructional System Design. vol, 4, 37-49.

52. Muruganantham, G. (2015). Developing of E-content package by using ADDIE model. International Journal of Applied Research, 1(3), 52-54.

53. Napratilora, M., \&Siagian, S. Y. (2019). Tenses Understanding in Using the English Language. English Journal Of Indragiri, 3(1), 29-38.

54. Nguyen, H. (2016, November 17). ADDIE is flexible. Retrieved November 19, 2019, from http://thelearningoak.com/index.php/2016/11/17/addie-is-flexible/.

55. Nichols Hess, A., \& Greer, K. (2016). Designing for engagement: Using the ADDIE model to integrate high-impact practices into an online information literacy course. Communications in information literacy, 10(2), 6.

56. O'Leary, Z. (2014). The essential guide to doing your research project (2nd ed.). Thousand Oaks, CA: SAGE Publications, Inc.

57. O'Neill, J. L. (2017). Weeding with ADDIE: Developing training for deselection at an academic library. Reference \& User Services Quarterly, 56(2), 108-115.

58. Pedder, D. (2006). Are small classes better? Understanding relationships between class size, classroom processes and pupils' learning. Oxford Review of Education, 32(02), 213-234.

59. Rahman, M. S., \& Ali, M. M. (2015). Problems in Mastering English Tense and Aspect and the Role of the Practitioners. IOSR Journal of Humanities and Social Science, 20(1), 131-135.

60. Rani, PM Usha."Remediation Through a Paradigm Shift in English Language Teaching. "International Journal of English and Literature (IJEL) 4. 5, Oct 2014, 11-18

61. Raoufi, K., Manoharan, S., \&Haapala, K. R. (2019). Synergizing Product Design Information and Unit Manufacturing Process Analysis to Support Sustainable Engineering Education. Journal of Manufacturing Science and Engineering, 141(2), 021018.

62. Richards, J. (2006). Comunicative language teaching today. Cambridge university press.

63. Richards, J. C., \& Renandya, W. A. (Eds.). (2002). Methodology in language teaching: An anthology of current practice. Cambridge university press.

64. Salaberry, R. (2002). Tense and aspect in the selection of Spanish past tense verbal morphology. Language Acquisition and Language Disorders, 27, 397-416.

65. Sanmuganathan, K. (2014). Impact of L1 on ESL (English as a Second Language) Writings of the Undergraduates of University of Jaffna.

66. Shuttleworth, M. (2008) Case Study Research Design. https://explorable.com/case-study-research-design

67. Suwannaporn, P., \&Speece, M. (2003). Marketing research and new product development success in Thai food processing. Agribusiness: An International Journal, 19(2), 169-188.

68. Taylor, L. (2004). Educational theories and instructional design models. Their place in simulation. Nursing Education and Research, Southern Health.

69. Thompson, D., \& Scheepers, C. (2013). Harmonizing the Passive: a new proposal for passive constructions in generative grammar. Newcastle Working Papers in Linguistics, 19(2), 74-96.

70. Thompson, D., Ferreira, F., \& Scheepers, C. (2018). One step at a time: representational overlap between active voice, be- 
passive, and get-passive forms in English. Journal of Cognition, 1(1), 35

71. Uzunboylu, H., \&Kosucu, E. (2017). Comparison and evaluation of Seels\& Glasgow and Addie instructional design model. Ponte, 73(6), 98-112.

72. Varpe, M. "Linguistic and Communicative Competence in English." International Journal of English and Literature 3.2 (2018): $11-14$.

73. Wahyuningtyas, E. W., \& Bram, B. (2018). Basic Tense Problems of the First Semester Students of English Language Education Study Program. International Journal of Indonesian Education and Teaching (IJIET), 2(2), 147-153.

74. Wang, S. (2010). The significance of English grammar to middle school students in China. Journal of Language Teaching and Research, 1(3), 313-319.

75. Yunus, M. M., Salehi, H., \& John, D. S. A. (2013). Using visual aids as a motivational tool in enhancing students interest in reading literary texts. arXiv preprint arXiv:1305.6360 